\title{
ADAPTATION OF THE FRAILTY INDEX FOR BRAZILIAN PORTUGUESE IN ADULT SPINE DEFORMITY SURGERY
}

\author{
ADAPTACÃO PARA O PORTUGUÊS DO BRASIL DO ÍNDICE DE FRAGILIDADE EM CIRURGIA \\ DE DEFORMIDADE DA COLUNA VERTEBRAL DO ADULTO
}

\section{ADAPTACIÓN PARA PORTUGUÉS DE BRASIL DEL ÍNDICE DE FRAGILIDAD EN CIRUGÍA DE DEFORMIDAD DE LA COLUMNA VERTEBRAL DEL ADULTO}

\author{
Raphael R Pratali, ${ }^{1}$ Carlos F W e Romerio, ${ }^{2}$ Murillo T Daher, ${ }^{3}$ Rodrigo Amaral, ${ }^{4}$ Igor M Cardoso, ${ }^{5}$ Charbel Jacob Jr, ${ }^{5}$ Emily K Miller, ${ }^{6}$ Justin S Smith, \\ Christopher P Ames, ${ }^{8}$ Carlos Fernando P S Herrero ${ }^{9}$
}

1. Hospital do Servidor Público Estadual, São Paulo, SP, Brazil.

2. Instituto de Coluna e Ortopedia de Recife (InCore), Recife, PE, Brazil.

3. Centro de Reabilitação e Readaptação Dr. Henrique Santillo (CRER), Goiânia, GO, Brazil.

4. Instituto de Patologia da Coluna, São Paulo, SP, Brazil.

5. Hospital da Santa Casa de Misericórdia de Vitória, Vitória, ES, Brazil.

6. Stanford University Department of Physical Medicine \& Rehabilitation, Palo Alto, CA, USA.

7. University of Virginia Health System, Charlottesville, VA, USA

8. University of California, San Francisco, CA, USA.

9. Universidade de São Paulo (USP), Faculdade de Medicina de Ribeirão Preto, Ribeirão Preto, SP, Brazil.

\begin{abstract}
Objectives: To adapt the adult spinal deformity frailty index (ASD-FI), which was presented as an instrument for stratification of risk of surgical complications, for application in the Brazilian population. Methods: This is a consensus-building study, following the Delphi method, in which a team of six Brazilian spine surgery specialists worked alongside the International Spine Study Group (ISSG), the group responsible for preparing the original version of the ASD-FI, in order to adapt the index for the Brazilian population. The variables to be included in the new version, as well as the translation of the terminology into Portuguese, were evaluated and a consensus was considered to have been reached when all (100\%) of the Brazilian experts were in agreement. Results: A version of the ASD-FI was created, composed of 42 variables, with the inclusion of two new variables that were not included in the original version. The new version was then back translated into English and approved by the ISSG members, resulting in the adapted version of the ASD-FI for the Brazilian population. Conclusion: This study presents an adapted version of the adult spinal deformity frailty index for the Brazilian population, for the purpose of risk stratification in the surgical treatment of these complex deformities. Level of evidence II; Study of adaptation of a valid score.
\end{abstract}

Keywords: Aging; Frailty; Scoliosis; Complications.

\section{RESUMO}

Objetivos: Adaptar o Índice de Fragilidade para Deformidade da Coluna Vertebral do Adulto (IF-DCVA), apresentado como instrumento para estratificação de risco para complicações cirúrgicas, para aplicação na população brasileira. Métodos: Trata-se de um estudo de criação de consenso, seguindo o método Delphi, em que uma equipe de seis especialistas brasileiros em cirurgia da coluna trabalhou em conjunto com o International Spine Study Group (ISSG), grupo responsável pelo desenvolvimento da versão original do IF-DCVA, a fim de adaptar o índice para a população brasileira. As variáveis a serem incluídas na nova versão, assim como a tradução da terminologia para o português foram avaliadas e foi considerado consenso quando todos (100\%) os especialistas brasileiros chegaram a um acordo. Resultados: Uma versão do IF-DCVA foi criada, composta por 42 variáveis, com a inclusão de duas novas variáveis que não faziam parte da versão original. A nova versão foi, então, retrotraduzida para o inglês e aprovada pelos membros do ISSG, resultando na versão adaptada do IF-DCVA para a população brasileira. Conclusões: O presente estudo apresenta uma versão adaptada do Índice de Fragilidade para Deformidade da Coluna Vertebral do Adulto para a população brasileira com o objetivo de avaliar a estratificação de risco no tratamento cirúrgico dessas deformidades complexas. Nível de evidência II; Estudo de adaptação de um escore válido.

Descritores: Envelhecimento; Fragilidade; Escoliose; Complicações.

\section{RESUMEN}

Objetivos: Adaptar el Índice de Fragilidad para Deformidad de la Columna Vertebral del Adulto (IF-DCVA), presentado como instrumento para estratificación de riesgo para complicaciones quirúrgicas, para aplicación en la población brasileña. Métodos: Se trata de un estudio de creación de consenso, siguiendo el método Delphi, en el que un equipo de seis especialistas brasileños en cirugía de columna trabajó junto con el International Spine Study Group (ISSG), grupo responsable por el desarrollo de la versión original de IF-DCVA, a fin de adaptar el índice para la población brasileña. Las variables a ser incluidas en la nueva versión, así como la traducción de la terminología para el portugués de Brasil fueron evaluadas y se consideró consenso cuando todos (100\%) los especialistas brasileños llegaron a un acuerdo. Resultados: Fue creada una versión del IF-DCVA, compuesta por 42 variables, con la inclusión de dos nuevas variables que no formaban 
parte de la versión original. La nueva versión fue entonces retrotraducida al inglés y aprobada por los miembros del ISSG, lo que resultó en la versión adaptada del IF-DCVA para la población brasileña. Conclusiones: El presente estudio presenta una versión adaptada para la población brasileña del Índice de Fragilidad para la Deformidad de la Columna Vertebral del Adulto, con el objetivo de evaluar la estratificación de riesgo en el tratamiento quirúrgico de esas deformidades complejas. Nivel de evidencia II; Estudio de adaptación de una escala válida.

Descriptores: Envejecimiento; Fragilidad; Escoliosis; Complicaciones.

\section{INTRODUCTION}

Interest in the treatment of adult spinal deformity (ASD) has increased in recent years. One reason for this is the global trend of population aging and the consequent increase in these deformities. ${ }^{1}$ It is recognized that ASD can lead to severe functional disability ${ }^{1-3}$ and it is not uncommon for patients to seek surgical treatment. ${ }^{4}$ However, the rate of complications related to surgical treatment of ASD is relatively high, ${ }^{5-7}$ and the preoperative recognition of associated risk factors is important.

Frailty is a relatively new clinical diagnosis that is characterized by a reduction in physiological function, leading to greater vulnerability to the development of diseases and death. ${ }^{8}$ This vulnerability may occur at different times in different people, with a discrepancy between physiological age and chronological age. Therefore, the evaluation of frailty has been used to quantify the individual's physiological age, in order to more accurately predict functional decline as compared to chronological age. ${ }^{8}$

Recently, frailty has been used as an important predictor of the risk of complications and adverse events related to surgery. ${ }^{9-11}$ Some methods used to quantify an individual's frailty were developed and validated, ${ }^{12-14}$ and a methodology for creating specific frailty quantification indices for a given population has been developed. ${ }^{14}$ Following this methodology, an index to quantify frailty was developed in order to stratify the risk of patients undergoing surgical treatment for ASD, using a multicenter database of North American services. ${ }^{15}$ Subsequently, this index was validated internationally, including with patients from European services. ${ }^{16}$ Both studies showed a significant correlation with the rate of complications, reoperation and prolonged hospitalization.

The objective of the present study was to adapt the frailty index in the surgical treatment of ASD (ASD-FI) for application in the Brazilian population.

\section{METHODS}

This is a consensus study, following the Delphi method ${ }^{17,18}$ in which a team of six Brazilian spine surgery specialists, with experience in the treatment of ASD, worked alongside the International Spine Study Group (ISSG), the group responsible for preparing the original version of the ASD-FI, in order to adapt the index for the Brazilian population. As this is a consensus building study involving adaptation of a score, and does not involve the data of any individual patient, it was not necessary to submit the study to the research ethics committee, and neither was an informed consent form necessary.

The original English version comprises forty variables (Table 1) to be scored in a binary manner, i.e. present or absent. ${ }^{15}$ The mean score of all the variables calculated results in the frailty index, with scores ranging from 0 to 1 . Patients with scores below 0.3 are considered not frail; those with scores between 0.3 and 0.5 are considered frail, and those with scores above 0.5 are considered severely frail. ${ }^{15}$ Initially, each Brazilian specialist, working individually and independently, developed their version of the ASD-FI, using the variables that applied to the context of patients in their practice, as well as the terminology in Portuguese to be used. Based on the original English version, each specialist was asked to exclude any variable that they did not consider applicable to the Brazilian population, and to include any they considered important but that were not included in the original version.

The six resulting versions were compared, and the divergences and discrepancies were discussed in videoconferencing sessions, followed by a final face-to-face meeting to complete the version
Table 1. Original variables of the Adult Spinal Deformity Frailty Index. ${ }^{15}$

\begin{tabular}{c}
\hline Health Deficits \\
\hline Documented by physician \\
\hline 3 Medical problems \\
\hline Body mass index $<18.5$ or $>30 \mathrm{~kg} / \mathrm{m} 2$ \\
\hline Cancer \\
\hline Cardiac disease \\
\hline Currently on disability \\
\hline Depression \\
\hline Diabetes \\
\hline Hypertension \\
\hline Liver disease \\
\hline Lung disease \\
\hline Osteoporosis
\end{tabular}

Peripheral vascular disease

Previous blood clot (deep vein thrombosis/pulmonary embolism/stroke) Smoking status

Patient-reported (questionnaire, question no.)

Bladder incontinence

Bowel incontinence

Deteriorating health this year (SF-36v2, 2)

Difficulty climbing 1 flight of stairs (SF-36v2, 3e)

Difficulty driving a car (LSDI, 3)

Difficulty getting dressed (SF-36v2, 3j; LSDI, 1/2)

Difficulty getting in/out of bed (LSDI, 6)

Difficulty sleeping $>6$ hours (ODI, 7)

Difficulty walking 100 yards (SF-36v2, 3i)

Difficulty with light activity (SF-36v2,3b)

Feeling downhearted/depressed most of the time (SF-36v2, 9f; SRS-22r, 16) Feeling tired most of the time (SF-36v2, 9i)

Feeling worn out most of the time (SF-36v2, 9g)

General health: fair/poor (SF-36v2, 1)

Inability to bathe without assistance (SF-36v2, 3j; LSDI, 8)

Inability to cheer up often (SF-36v2, 9c; SRS-22r, 7)

Inability to do normal work/schoolwork/housework (ODI, 10; SRS-22r, 9/12)

Inability to lift heavy objects (SF-36v2, 3c; ODI, 3)

Inability to travel $>1$ hour (ODI, 9)

Inability to walk without assistive device (ODI, 4)

Leg weakness

Loss of balance

Not in excellent health (SF-36v2, 11d)

Personal care dependency (ODI, 2)

Restricted activity level (SRS-22r, 5)

Restricted social life (ODI, 8; SRS-22r, 14/18)

LSDI indicates Lumbar Stiffness Disability Index; ODI, Oswestry Disability Index; SF-36v2, Shor Form-36, version 2; SRS-22r, Scoliosis Research Society-22r questionnaire.

adapted for the Brazilian population. A consensus was reached when all six specialists agreed on the inclusion or exclusion of a variable and on the Portuguese terminology to be used. This first version of the ASD-FI adapted for the Brazilian population was back translated into English by a bilingual translator, fluent in Portuguese but whose native language was English, and unaware of the concepts used. The back translated version of the ASD-FI was sent to the ISSG members for their approval. 


\section{RESULTS}

There were wide discrepancies among the six versions elaborated by the Brazilian specialists, particularly in regard to the Portuguese terminology used for the suggested variables. A professional with a degree in Portuguese helped to determine the most appropriate terminology and grammar to be used, until a consensus was reached among all the experts.

Concerning the variables suggested by the Brazilian experts, none of their versions excluded any item from the original version of the ASD-FI. However, some included variables that do not appear in the original version. These variables were discussed at the meetings between the specialists, and the opinions of the ISSG members were also considered. Finally, the inclusion of two new variables was agreed by consensus, making a total of 42 variables in the version adapted for the Brazilian population (Appendix Table 1).

The division of factors between "documented by the physician" based on medical records or patient history, and "reported by the patient" was maintained, from the response to a questionnaire with questions derived from the following questionnaires, translated and validated into Brazilian Portuguese: the Oswestry Disability Index (ODI), Scoliosis Research Society-22 (SRS-22) and the Lumbar Stiffness Disability Index (LSDI). ${ }^{19-21}$ The binary score (present or absent) for each variable was maintained, as was the categories of scores indicating not frail patients (less than 0.3), frail (between 0.3 and 0.5 ) and severely frail (between 0.5 and 1 ). As proposed in the original English version of the ASD-FI, at least $75 \%$ of the variables must be completed in order to validate the individual's frailty INDEX score. Thus, in the version adapted for the Brazilian population, 32 variables must be completed.

\section{DISCUSSION}

The rate of complications associated with surgical treatment of ASD is known to be high. ${ }^{5-7}$ Risk stratification is therefore crucial for planning the surgical strategy, including the use or non-use of osteotomies and postoperative management. ${ }^{15}$ Recently, it has been demonstrated that identifying frailty in patients with ASD is associated with an increased rate of complications, reoperation and length of hospital stay. ${ }^{15,16}$ The ASD-FI can be used as a tool for risk stratification, based on the patient's physiological status and comorbidities rather than on chronological age.

The original version of the ASD-FI, developed by the ISSG, followed the method proposed by Searle and collaborators, ${ }^{14}$ based on the concept that the number of health problems should be considered in order to determine and quantify an individual's frailty. Such health problems should be identified in order to determine the functional capacity for daily activities, such as mobility, cognitive, mood, and medical comorbidities. The variables of the frailty index relate to health problems, and their prevalence should follow these criteria: increase with age, be related to health status, and not be depleted early. ${ }^{14,15}$

The ASD-FI includes forty variables, selected according to the above principles. An individual's state of frailty is attributed a score, based on the sum total of health problems and functional deficits. ${ }^{15}$ Working alongside the members of the ISSG responsible for the elaboration of the ASD-FI, this study aimed to adapt the index for the Brazilian population, in order to universalize its use as an instrument of risk stratification in ASD surgery. For this adaptation, a panel of specialists in the surgical treatment of ASD met to determine, through consensus, the variables to be included and that would represent the most frequent health problems in the practice of these Brazilian specialists.
The forty variables that make up the original version were maintained and, by consensus among the Brazilian experts, two variables were added in the version adapted for the Brazilian population. These variables followed the criteria proposed by Searle and collaborators, ${ }^{14}$ discussed above, and were accepted by the ISSG members. The two new variables included were: Nervous System Disease and Hypoalbuminemia. Nervous System Disease can be exemplified by Parkinsonism, which has increased prevalence with age and is recognized as being associated with spinal deformity and higher rates of surgical complications. ${ }^{22,23}$ Albumin is the most abundant plasma protein, and hypoalbuminemia, recognized as a serum dose lower than $3.5 \mathrm{~g} / \mathrm{dL}$, is one of the main indicators of malnutrition. ${ }^{24,25}$ The prevalence of hypoalbuminemia also increases with aging. ${ }^{25}$ The rate of complications in spine surgery is directly linked to malnutrition, ${ }^{26}$ which is why hypoalbuminemia research, as a marker of malnutrition, was included in the version of the ASD-FI adapted for the Brazilian population.

The main limitation of the present study is that the adapted version of the ASD-FI for the Brazilian population was not tested as a tool for risk stratification in ASD surgery. In both studies, both the original version of the index and the external validation version for the European population were considered retrospective data to demonstrate the correlation between increased chance of complications and more prolonged hospitalization times and more severe patient frailty. ${ }^{15,16}$ Considering that the epidemiological profiles of patients undergoing surgical treatment for ASD are similar (generally older individuals with comorbidities) and the complexity of the surgical procedures, it is hypothesized that the correlation found in previous studies, between frailty and increased rate of complications, is comparable to that found for the adapted version for the Brazilian population of the ASD-FI. However, we could not analyze this factor due to the lack of adequate retrospective database, but we intend to perform this analysis prospectively in future studies.

\section{CONCLUSION}

This study presents an adapted version for the Brazilian population of the adult spinal deformity frailty index (ASD-FI), for the purpose of risk stratification in the surgical treatment of these complex deformities and procedures.

Conflicts of interest: In relation to the manuscript titled "Adaptation of the frailty index for Brazilian Portuguese in adult spine deformity surgery", the author Justin S Smith declares the following conflicts of interest: Grants for Speaking/teaching arrangements from Zimmer Biomet, NuVasive and K2M; as Consultant from Zimmer Biomet, Nuvasive and K2M; Research Study group funding from DePuy Synthes; fellowship funding from NREF and AOSpine. The author Christopher P Ames declares the following conflicts of interest: Grants as royalties from Stryker, Biomet Zimmer Spine, DePuy Synthes, Nuvasive, Next Orthosurgical, K2M and Medicrea; as consulting from DePuy Synthes, Medtronic, Stryker, Medicrea, K2M and Biomet Zimmer; research funding from Titan Spine, DePuy Synthes and ISSG; grant funding from SRS; he is member of Editorial Board of Operative Neurosurgery, executive committee of the ISSG and director of Global Spinal Analytics.

CONTRIBUTION OF THE AUTHORS: Each author made significant individual contributions to this manuscript. RRP conceived and designed the study participated in the adaptation of the frailty index for Brazilian population and was responsible for the data analysis and drafting the manuscript. MTD participated in the adaptation of the frailty index for Brazilian population and was responsible for the data analysis. CFWER helped draft the manuscript RA, IMC and CJ participated in the adaptation of the frailty index for the Brazilian population. EKM and JSS conceived and designed the study and approved the back translation of the frailty index into English. CPA conceived and designed the study. CFPSH conceived and designed the study, and was responsible for the data analysis and critical revision of the manuscript. All the authors reviewed the final version of the manuscript before its submission. 


\section{REFERENCES}

1. Pratali R, Diebo B, Schwab F. Adult Spine Deformity - An overview of radiographic and clinical considerations. Coluna/Columna. 2017;16(2):149-52.

2. Bess S, Line B, Fu KM, McCarthy I, Lafage V Schwab F, et al. The health impact of symptomatic Adult Spinal Deformity: Comparison of deformity types to United States population norms and chronic diseases. Spine (Phila Pa 1976). 2016;41(3):224-33.

3. Pellisé $F$, Vila-Casademunt $A$, Ferrer M, Domingo-Sàbat $M$, Bagó J, Pérez-GruesoFJ, et al. Impact on health related quality of life of adult spinal deformity (ASD) compared with other chronic conditions. Eur Spine J. 2015;24(1):3-11.

4. Smith JS, Lafage V, Shaffrey $\mathrm{Cl}$, Schwab F, Lafage R, Hostin R, et al. Outcomes of Operative and Nonoperative Treatment for Adult Spinal Deformity: A Prospective, Multicenter, Propensity-Matched Cohort Assessment With Minimum 2-Year Followup. Neurosurgery. 2016;78(6):851-6.

5. Smith JS, Sansur CA, Donaldson III WF, Perra JH, Mudiyam R, Choma TJ, et al. Short-term morbidity and mortality associated with correction of thoracolumbar fixed sagittal plane deformity A report from the Scoliosis Research Society Morbidity and Mortality Committee. Spine (Phila Pa 1976). 2011;36(12):958-64.

6. Kelly MP. Lenke LG, Shaffrey $\mathrm{Cl}$, Ames CP Carreon LY Lafage V et al. Evaluation of complications and neurological deficits with three-column spine reconstructions for complex spinal deformity: a retrospective Scoli-RISK-1 study. Neurosurg Focus. 2014;36(5):E17.

7. Pratali RR, Martins SM, Santos FPE, Barsotti CEG, Oliveira CEAS. The use of threecolumn osteotomy in the treatment of rigid deformities of the adult spine. Rev Bras Ortop. 2018:53(2):213-20.

8. Morley JE, Vellas B, van Kan GA, Anker SD, Bauer JM, Bernabei R, et al. Frailty consensus: a call to action. J Am Med Dir Assoc. 2013;14(6):392-7.

9. Farhat JS, Velanovich V, Falvo AJ, Horst HM, Swartz A, Patton JH Jr, et al. Are the frail destined to fail? Frailty index as predictor of surgical morbidity and mortality in the elderly. J Trauma Acute Care Surg. 2012:72(6):1526-30; discussion 30-1.

10. Joseph B, Pandit V, Sadoun M, Zangbar B, Fain MJ, Friese RS, et al. Frailty in surgery. J Trauma Acute Care Emerging. 2014;76(4):1151-6.

11. Kim SW, Han HS, Jung HW, Kim KI, Hwang DW, Kang SB, et al. Multidimensional frailty score for the prediction of postoperative mortality risk. JAMA Surg. 2014:149(7):633-40.

12. Cigolle CT, Ofstedal MB, Tian Z, Blaum CS. Comparing models of frailty: the Health and Retirement Study. J Am Geriatr Soc. 2009;57(5):830-9

13. Clegg A, Young J, lliffe S, Rikkert MO, Rockwood K. Frailty in elderly people. Lancet 2013:381(9868):752-62.
14. Searle SD, Mitnitski A, Gahbauer EA, Gill TM, Rockwood K. A standard procedure for creating a frailty index. BMC Geriatr. 2008:8:24.

15. Miller EK, Neuman BJ, Jain A, Daniels AH, Ailon T, Sciubba DM, et al. An assessment of frailty as a tool for risk stratification in adult spinal deformity surgery. Neurosurg Focus. 2017;43(6): E3.

16. Miller EK, Vila-Casademunt A, Neuman BJ, Sciubba DM, Kebaish KM, Smith JS, et al. External validation of the adult spinal deformity (ASD) frailty index (ASD-FI). Eur Spine J. 2018:27(9):2331-8.

17. Hsu CS, Sandford BA. The Delphi technique: making sense of consensus. Pract Assess Res Eval. 2007;12(10):1-8

18. Pratali RR, Hennemann SA, Amaral R, Da Silva LECT, De Carvalho MOP, Daher MT, et al. Standardized terminology of adult spine deformity for Brazilian Portuguese. Coluna/Columna. 2015;14(4):281-5

19. Vigatto R, Alexandre NM, Correa Filho HR. Development of a Brazilian Portuguese version of the Oswestry Disability Index: cross-cultural adaptation, reliability, and validity. Spine (Phila Pa 1976). 2007:32(4):481-6.

20. Carrico G. Meves R, Avanzi O. Cross-cultural adaptation and validity of an adapted Brazilian Portuguese version of Scoliosis Research Society-30 questionnaire. Spine (Phila Pa 1976). 2012;37(1):E60-3.

21. Guarconi Netto A, Marchi L, Pokorny G, Amaral R, Jensen R, Pratali R, et al. Crosscultural translation and adaptation of the lumbar stiffness disability questionnaire (LSDI) for Brazilian. Coluna/Columna. 2019;18(2). (Ahead of print)

22. Oichi T, Chikuda H, Ohya J, Ohtomo R, Morita K, Matsui H, et al. Mortality and morbidity after spinal surgery in patients with Parkinson's disease: a retrospective matched-pair cohort study. Spine J. 2017;17(4):531-7.

23. Bouyer B, Scemama $C$, Roussouly $P$, Laouissat $F$, Obeid I, Boissière $L$, et al. Evolution and complications after surgery for spine deformation in patients with Parkinson's disease. Orthop Traumatol Surg Res. 2017;103(4):517-22.

24. Franch-Arcas G. The meaning of hypoalbuminaemia in clinical practice. Clin Nutr. $2001 ; 20(3): 265-9$

25. Santos Neto DB, Pratali R, Martins SM, Barsotti CEG, Oliveria CE. Nutritional and vitamin $\mathrm{D}$ status in a Brazilian sample of patients undergoing spinal surgery. Global Spine Journal. 2017;6(1 suppl):s-0036-1582923.

26. Lenke LG, Bridwell KH, Blanke K, Baldus C. Prospective analysis of nutritional status normalization after spinal reconstructive surgery. Spine (Phila Pa 1976). 1995;20(12):1359-67.

Appendix Table 1. Variables resulting from the process of translation of the Adult Spinal Deformity Frailty Index for Brazilian Portuguese.

Indice de Fragilidade para cirurgia na Deformidade da Coluna Vertebral do Adulto.

Cada um destes itens, se presente, recebe 1 ponto. Caso contrário 0. Faça a média (não considere os itens não reportados).

Itens documentados pelo médico (Prontuário Médico)

$\cdot \mathrm{IMC}>30$ ou $<25$

- 3 comorbidades

- Diabetes

- Câncer

- Doenca cardíaca

- Hipertensão Arterial Sistêmica (HAS)

- Doença Renal

- Doença hepática

- Doenca pulmonar

- Evento tromboembólico prévio (trombose venosa profunda/embolia pulmonar/acidente vascular cerebral)

- Osteoporose

- Tabagismo

- Doenca vascular periférica

- Depressão

- Hipoalbuminemia (Albumina sérica $<3.5 \mathrm{~g} / \mathrm{dL}$ )

- Doença do Sistema Nervoso

Itens relatados pelo paciente (questionário; $\mathrm{n}^{\circ}$ da questão)

1. Incontinência fecal

2. Fraqueza nas pernas

3. Incontinência urinária

4. Perda do equilíbrio

5. Paciente incapacitado para o trabalho

6. Piora da saúde no último ano (SF-36; questão 2; pontuação 0,1,2)

7. Dificuldade para subir 1 lance de escada (SF-36; questão 3e; pontuação 0,1,2

8. Dificuldade para dirigir carro (LSDI: questão 3 Carro: pontuacão 34.5 )

9. Dificuldade para se vestir (SF-36; questão 3j: pontuação 0,1,2 E/OU LSDI; questão 1 Vestir-se; pontuacão 3,4,5 E/OU LSDI; questão 2 Vestir-se; pontuação 3,4,5)

10. Dificuldade para deitar ou levantar da cama (LSDI; questão 6 Cama; pontuação $3,4,5)$

11. Dificuldade para dormir $>6$ horas (ODl; questão 7 Dormir; pontuação $3,4,5$ )

12. Dificuldade para caminhar sem auxílio de bengala ou muleta ou andador (SF- 36; questão 3i; pontuação 0,1,2 E/OU ODI; questão 4 Andar; pontuação 3,4,5)

13. Dificuldade para atividades leves (SF-36; questão 3b; pontuacão 0,1,2)

14. Sentindo-se desanimado ou deprimido a maior parte do tempo (SF-36; questão 9f; pontuação 0,1,2 E/OU SRS22r; questão 16; pontuação 2,1)

15. Sentindo-se cansado a maior parte do tempo (SF-36; questão 9i; pontuação 0,1,2)

16. Sentindo-se esgotado a maior parte do tempo (SF-36; questão 9g; pontuaç̃o 0,1,2

17. Saúde geral: ruim/muito ruim (SF-36; pontuação 1; pontuação 4/5)

18. Incapacidade de tomar banho sem auxílio (SF-36; questão 3j; pontuação 0,1,2 E/OU LSDI; questão 8 Tomar banho; pontuação 3,4,5)

19. Incapacidade de se animar com frequência (SF-36; questão 9c; pontuação 0,1,2 E/OU SRS22r; questão 7; pontuação 2,1)

20. Incapacidade para realizar atividades regulares no trabalho/escolares/domésticas (ODI; questão 10 Emprego; pontuação 3,4,5 E/OU SRS22r; questão 9; pontuação 2,1 E/OU SRS22r; questão 12; pontuação 2,1)

21. Incapacidade de levantar objetos pesados (SF-36; questão 3c; pontuação 0,1,2 E/OU ODI; questão 3 Levantar peso; pontuação 3,4,5)

22. Incapacidade de se locomover $>1$ hora (ODI; questão 9 Locomoção; pontuação 3,4,5)

23. Saúde não excelente (SF-36; questão 11d; pontuação 4/5)

24. Dependência para cuidados pessoais (ODI; questão 2 Cuidados pessoais; pontuacão 3,4,5)

25. Restricão do nível de atividade (SRS22r; questão 5; pontuacão 2,1)

26. Restrição da vida social (ODI; questão 8 Vida pessoal; pontuação 3,4,5 E/OU SRS22r; questão 14; pontuação 2,1 E/OU SRS22r; questão 18; pontuação 2,1)

LSDI: Lumbar Stiffness Disability Index; ODI: Oswestry Disability Index; SF-36: Short Form-36; SRS-22, Scoliosis Research Society-22.

Eu classifico a pessoa como nẫo-frágil (pontuação menor que 3 ou 0,3), frágil (3-5 ou 0,3-0,5) e gravemente frágil (maior que 5 ou 0,5).

Se o paciente tiver menos que 32 variáveis preenchidas, do total das 42 , ele não poderá ser classificado pelo escore de fragilidade. 